\title{
Gene Pyramiding for Sustainable Crop Improvement against Biotic and Abiotic Stresses
}

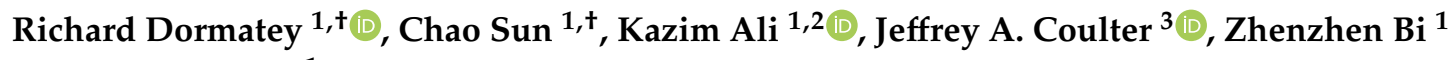 \\ and Jiangping Bai ${ }^{1, *}$ \\ 1 Gansu Provincial Key Laboratory of Aridland Crop Science, College of Agronomy, \\ Gansu Agricultural University, Lanzhou 730070, China; rmddormatey@gmail.com (R.D.); \\ sunc@gsau.edu.cn (C.S.); kazim76@gmail.com (K.A.); zhenzhenbigsau@gmail.com (Z.B.) \\ 2 National Institute for Genomics and Advanced Biotechnology, National Agricultural Research Centre, \\ Park Road, Islamabad 45500, Pakistan \\ 3 Department of Agronomy and Plant Genetics, University of Minnesota, Saint Paul, MN 55108, USA; \\ jeffcoulter@umn.edu \\ * Correspondence: baijp@gsau.edu.cn \\ + These authors contributed equally to this work.
}

Received: 21 July 2020; Accepted: 20 August 2020; Published: 26 August 2020

\begin{abstract}
Sustainable agricultural production is endangered by several ecological factors, such as drought, extreme temperatures, excessive salts, parasitic ailments, and insect pest infestation. These challenging environmental factors may have adverse effects on future agriculture production in many countries. In modern agriculture, conventional crop-breeding techniques alone are inadequate for achieving the increasing population's food demand on a sustainable basis. The advancement of molecular genetics and related technologies are promising tools for the selection of new crop species. Gene pyramiding through marker-assisted selection (MAS) and other techniques have accelerated the development of durable resistant/tolerant lines with high accuracy in the shortest period of time for agricultural sustainability. Gene stacking has not been fully utilized for biotic stress resistance development and quality improvement in most of the major cultivated crops. This review emphasizes on gene pyramiding techniques that are being successfully deployed in modern agriculture for improving crop tolerance to biotic and abiotic stresses for sustainable crop improvement.
\end{abstract}

Keywords: gene pyramiding; marker-assisted selection; stress resistance; crop improvement

\section{Introduction}

The green revolution has resulted in substantial progress in yield and quality improvement of important food crops globally [1]. However, the conventional crop-breeding method is insufficient for advancing crop improvement at the rate that is necessary to meet the food requirement for the steadily increasing human population [2,3]. The Food and Agriculture Organization estimated that worldwide food production must be increased by $70 \%$ by 2050 in order to meet the food demand of the expanding population [4]. Thus, to meet the increasing food demand, smart and rapid crop-breeding tools are required to simultaneously improve multiple agronomic and nutritional traits [5].

There are several yield-reducing factors in food grains, and it is estimated that annual losses are about $25 \%$ and $6-25 \%$ globally due to biotic and abiotic stresses, respectively [6,7]. In many developing countries, environmental stresses are severely affecting agricultural production [8]. The most important biotic stressors of food crops are plant diseases and insect pests [9]. There are diverse and widespread insect pests and pathogens that are a challenge for sustainable agriculture [10]. During the recent years, an outbreak of a single insect pest, fall armyworm (Spodoptera frugiperda L.), across sub-Saharan 
Africa, India, Bangladesh, Sri Lanka, Thailand, and China has damaged more than 80 plant species, including fruits, vegetables, staple foods (maize, rice, sorghum, and millet), and cash crops (cotton and sugarcane) in these regions and has threatened food security and caused huge economic losses [11-14]. Therefore, appropriate and effective control strategies are required for the control of these biological threats to avoid food and economic losses across the globe.

Chemical pesticides have been used to reduce biotic damage of crops for several years, but recently the use of chemical pesticides has been discouraged due to many adverse factors, such as high product cost and the need for multiple applications, which is unaffordable by the majority of small-scale farmers [15]. In addition, chemical pesticides are a serious hazard to human health and the environment [16]. Pest resistance to chemical pesticides is another problem. In a recent report, herbicide resistance was documented in 262 weed species globally [17] Novel approaches for pest control are required for sustainable agricultural production in order to minimize the dependence on pesticides and protect the environment and beneficial micro fauna [18]. Contrary to chemical control, the development of pest-resistant crop cultivars has become a popular idea that is durable, economical, and environment friendly [19]. It is of key significance to achieve durable and environmentally-friendly biotic stress tolerance in crops to ensure food security on a sustainable basis $[20,21]$.

Most crop-breeding strategies for biotic and abiotic stress resistance are based on the insertion of a single resistant gene into plants, and thus crop resistance only lasts for a short period of time [22,23]. Therefore, the development of genotypes with resistance against several stresses by pyramiding multiple genes from different sources into a single plant is now emphasized [24-27]. Crop stress tolerance development has been elucidated in several studies by the pyramiding of multiple resistance genes $[28,29]$ (Table 1). However, this technique has not been fully utilized for biotic stress resistance and crop quality enhancement in most of the major cultivated crops [27,30-32].

Abiotic stresses also adversely affect the growth and yield of crops [33], and these can even affect plant survival [34,35]. Every year, considerable crop losses occur due to floods [36]. Salinity is another problem for crop production and most crop plants are sensitive to salts throughout their life cycle and especially at the seedling stage [37]. There are also some salt-resistant crop varieties that express salt-responsive genes to tolerate excessive salts, and the quantitative trait locus (QTLs) linked with these genes may be mapped through microsatellite markers for breeding of salt-tolerant lines [38,39]. The cultivar, NonaBokra, which is tolerant to salt, was successfully mapped with SKC1, and conserves $\mathrm{K}^{+}$homeostasis under salinity $[40,41]$. Similarly, many goals have been achieved in the development of drought-tolerant traits in other crops through marker-assisted breeding methods [42]. Many drought-tolerant genes have been explored and successfully engineered in many crops for the development of drought resistance [43,44]. Low-temperature tolerant genes (OsRAN1) and QTLs have also been identified in many plants for further use in cold-tolerance development in crop varieties through molecular marker breeding tools [45-47]. Yet, gene pyramiding has not been fully utilized in the area of abiotic stress improvement for durable resistance.

The incidence of crop stresses has necessitated the adoption of superior and innovative technologies to protect yield potential of various crops under stressful growing conditions. However, a problem in the improvement of crops through traditional breeding methods is that not only the desired genes, but some unwanted genes, continue to exist even after several backcross generations and the ability to screen for these is not easy. Compared to traditional breeding, advances in molecular technologies have led to precise, sophisticated, and rapid breeding through molecular markers $[5,48]$. Marker-assisted selection (MAS) comprises indirect selection of traits with the marker linked with the desired gene for the tagging of some important agronomic trait that otherwise is not easy to mark for resistance against pathogens, diseases, and abiotic stresses and therefore protects against losses in yield and quality characteristics. Marker studies, especially on near isogenic lines (NILs) and bulk segregate or recombinant inbred lines (RILs), have hastened gene mapping in crops. Through the use of random amplified polymorphic DNA (RAPD), restriction fragment length polymorphism (RFLP), and microsatellite markers, sequence-tagged sites have been developed successfully in tomato 
(Lycopersicum esculentum L.), rice (Oryza sativa L.), wheat (Triticum aestivum L.), and many other cereals [27].

Resistance developed through a single gene can be overcome by pests after a few years [49-52], so it is necessary to develop unique and efficient strategies to enhance crop resistance against stresses to improve yield and quality on a sustainable basis [53-55]. Gene pyramiding may be one of the superior techniques to accomplish durable resistance against various stresses in crop production [56-58]. Sustainable improvement of crops by integrating multiple resistance genes is essential to ensure agricultural production across a range of climatic conditions [59]. In most cases, more than one gene controls a specific trait, so it is necessary to manipulate multiple genes for evolving resistance against biological and non-biological agents, such as chemicals, diseases, pests, and weeds [60]. For long-term and durable resistance development, the pyramiding of diverse resistance genes against a single pathogen or pest in a single genotype can help for long-term resistance development [20,58,61-63]. Marker-assisted breeding could make it possible to effectively combine resistant genes into a single genetic background in the shortest possible time [64,65]. In this review, we highlight the advances made in gene pyramiding to address crop production challenges and also identify the limitations that need to be addressed in utilizing gene pyramiding techniques. A graphical presentation to combine different genes (gene pyramiding) from different parents into a single genotype is shown in Figure 1.

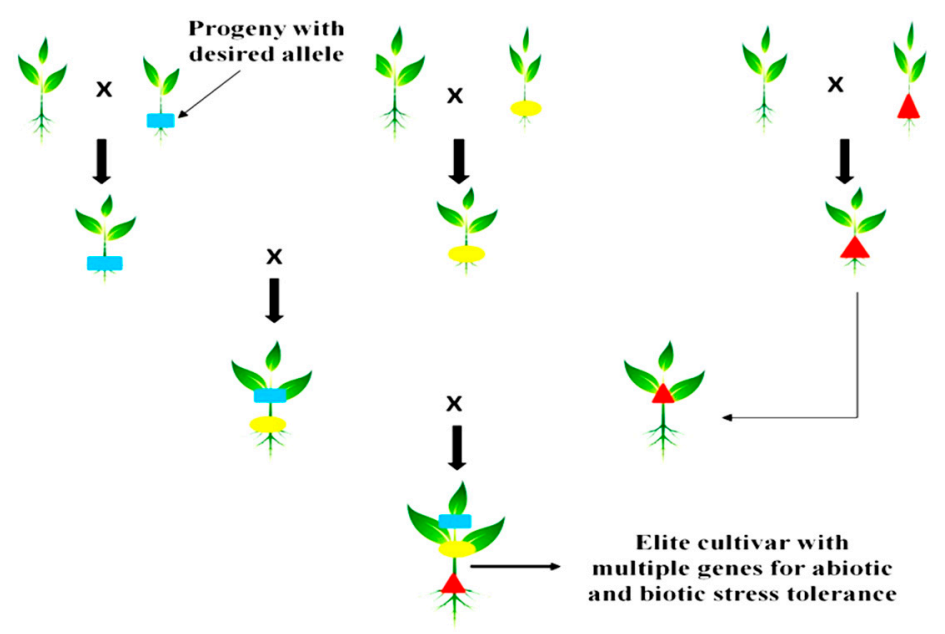

Figure 1. A graphical representation of gene pyramiding for sustainable crop improvement against biotic and abiotic stresses.

\section{Types of Gene Pyramiding in Plant Breeding}

Gene pyramiding is a crop-breeding technique that can be applied in conventional and advanced molecular breeding programs to introduce novel lines. The conventional technique of crop breeding develops new crop varieties by employing traditional techniques and routine natural processes, as compared to modern and sophisticated tools of the current era [66-68]. The technique involves sequential gene pyramiding deployed in the same plant. The conventional pyramiding technique involves backcross breeding: crossing a hybrid with one of the parental lines, followed by selection for the desired characteristic $[44,69]$. The inherited traits and resistant genes are transferred from donor parents into recipient lines by backcrossing, pedigree breeding, or recurrent selection. With backcrossing, the traits of interest are identified via the selection process. The backcrossing method is also used for resistance gene pyramiding [70]. Pedigree breeding is a method of genetic improvement of self-pollinated species in which superior genotypes are selected from segregating generations and proper records of the ancestry of selected plants are maintained at each stage of selection [69]. Recurrent selection is an efficient and modified form of progeny selection, where selection for some specific trait(s) is conducted within consecutive segregating progeny generations on the basis of phenotypic characteristics [71] (Figure 2A-D). 

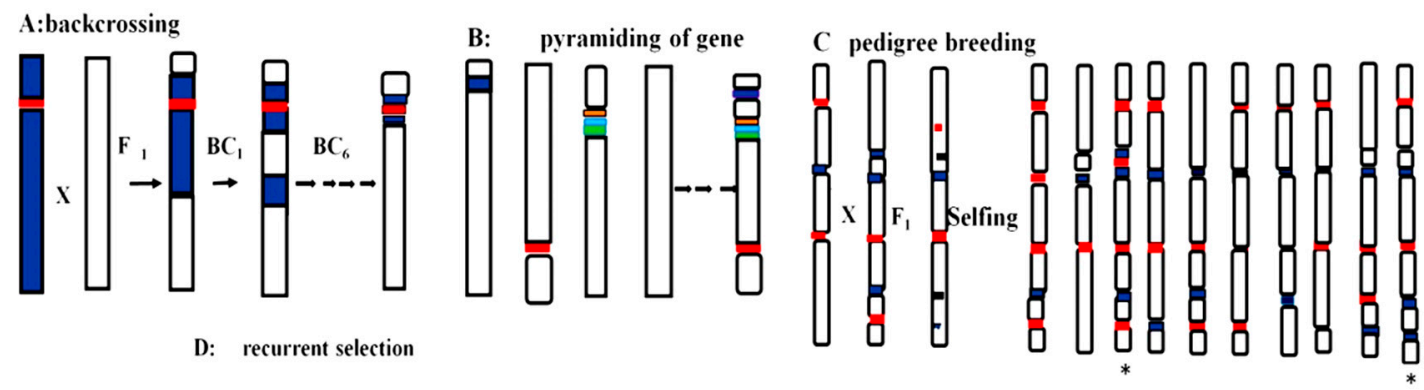

D: recurrent selection

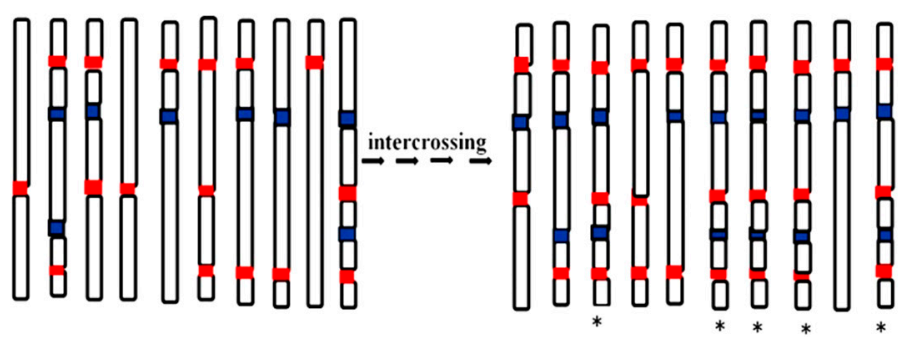

Figure 2. Conventional methods of plant breeding and selection. Each vertical bar is a graphical representation of an individual's genome within a breeding population, and the colored segments specify genes and/or QTLs that affect the selected traits. Genes associated with various behaviors are portrayed in different colors (i.e., red, blue). " $X$ " denotes a cross between parents, and the arrows represent the same form of successive crosses. An asterisk underneath an individual implies a desirable genotype. (A) Backcrossing. A donor genotype (blue bar) harboring a particular desirable gene (red) is crossed with an elite genotype targeted for enhancement (white bar), with offspring regularly crossed with the elite genotype. Each process of backcrossing includes selection for the interest gene and recovery of an increased proportion of the genome of the elite line. (B) Pyramiding of genes. By crossing and selection, genes/QTLs linked with different beneficial traits (blue, red, turquoise) are mixed into the same genotype. (C) Breeding the pedigree. Two individuals with suitable and compatible phenotypes are crossed; the $F_{1}$ offspring is self-pollinated to correct new, improved variations of the genotype. (D) Recurrent selection. An individual population (10 in each case) separates for two traits (red, blue), each of which is influenced by two major favorable QTLs. Individual intermingling and selection for suitable phenotypes/genotypes increases the frequencies of favorable alleles at each locus. No individual in the initial population had all desirable alleles in this example, but after recurrent selection, half the population possessed the desired genotype. Recurrent selection can be conducted in parallel for hybridized crops within two complementary populations to extract lines, which are then crossed to form hybrids; this process is called reciprocal recurrent selection [69,72].

The pyramiding scheme of the genes can be divided into two sections. The first element is called a pedigree, which is structured to cumulate all target genes in a single genotype called the root genotype. The second component is called the fixation stage to fix the target genes in a homozygous state to extract the ideal genotype [73]. A potential technique for the fixation steps is the generation of a population of doubled haploids from the root genotype. Genetically complex improvement of the germplasm traits requires the genome to be reshuffled to produce new favorable gene combinations in the progeny [72]. The pedigree breeding method produces such innovation for improved performance by crossing and recombining amongst superior complementary parents and selection among segregating progeny. Here, the genotypes receive a population of gametes, and their genetic material is multiplied. This leads to a population of fully homozygous individuals, which can include the ideotype. Using this technique, the ideal genotype can be obtained after the root genotype is obtained in just one additional generation, and there are chances of recovering transgressive segregants by the pedigree method. Moreover, this approach is useful for highly inherited traits, such as seed size, form, disease and insect resistance, height, and maturity. It is commonly used for disease resistant variety production, if it is controlled by major genes [74]. 


\section{Molecular Techniques in Breeding Programs}

Crop breeding has been improved to a great extent in recent years and now precision breeding has become possible in the shortest possible time with the advent of modern molecular tools. Innovative molecular breeding tools are being used to improve crop varieties, which mostly involve MAS and gene transformation. Single nucleotide polymorphisms and insertion deletions polymorphisms are abundantly found all over the genome of plants [75], and these are a good source for MAS in breeding programs [76]. Easy accessibility of polymorphic markers, linkage maps, and QTLs for different quantitative and qualitative traits have facilitated construction of inter- and intra-specific maps $[77,78]$. Quantitative trait loci have been identified and linked with resistance to many plant diseases [79]. The association of QTLs with yield-related traits has not been widely applied [80-82]. These can be used as a marker's linkage with key important genes for the selection and improvement of crops by stacking multiple traits into a variety through modern breeding tools [83].

\subsection{Molecular Marker-Assisted Selection}

Selection of a trait in plants through molecular markers normally involves identification of omic regions, which play a role in the expression of desirable genes [10]. Marker-assisted selection is involved in genotype identification, diversity and purity analysis, selection of parent lines, and the study of hybrid vigor [84]. It utilizes DNA-based markers that are directly linked with the targeted gene to help phenotypic evaluation and improvement of breeding efficiency by selecting the target genes within the germplasm, but not genetic engineering, which involves transfer of foreign gene sequences [85-87]. Marker-assisted selection has been effectively applied for stress resistance development and quality improvement in many important crops, such as rice (resistance to bacterial blight, blast, flood, and salinity and improvement in grain quality), wheat (resistance to leaf rust and powdery mildew), and cotton (resistance to insect pests) [88]. Previously, crop breeders used performance of plants and information obtained from them to conclude about their genetic makeup, but it was time consuming, strenuous, and not so efficient $[85,89]$. Thus, direct handling of genes that are involved in controlling specific traits can speed up the breeding process [74]. These traits may be monogenic or polygenic [74,85], and their locations are referred to as QTL, which may have a greater effect than others as major genes. Quantitative trait loci essentially refers to those genes that might be a good option for selection; however, it is difficult to find inheritance at QTLs only. Instead, QTLs help to locate marker sequence inheritance, close to or within the QTL. Selection of markers is done on the basis of closeness to QTLs, so sophisticated and well-organized procedures are adopted for the identification of marker sequences closely linked with major genes on the chromosomes [90]. The reliability of a phenotype should be accurately predicted by the markers, and these are commonly applied to confirm the trueness of the first filial generation $\left(\mathrm{F}_{1}\right)$, genetic purity testing of seeds, cultivars, linkage construction, genes, and QTL mapping associated with other biological and physiological functions [86]. The attributes of DNA-based markers for effective applications are their reliability and closeness to the trait of interest ( $<5 \mathrm{cM}$ genetic distance) [91]. It is also desirable that marker applications be convenient for researchers to handle with good reproducibility, and also simply and quickly. Hence, high output and quick methods of efficiency are important factors to be taken into account. These should also possess high polymorphism, have co-dominance inheritance for homo and hetero zygotes in segregating offspring, and be cost effective [92-94].

\subsection{Marker-Assisted Backcrossing}

Marker-assisted backcrossing (MABC), a simple form of marker-assisted selection, is currently being widely applied in molecular breeding [95]. Marker-assisted backcrossing targets one or more genes or QTLs transferred from one donor parent into another superior cultivar or genotype to improve a targeted trait. Contrary to conventional backcrossing, MABC depends on the alleles of a marker linked with desirable genes or QTLs instead of phenotypic performance. Through MABC, the outcomes 
can be obtained within a shorter period of time (about two years) [85]. In principle, MABC can be utilized in any crop-breeding program. Markers are helpful in the backcross selection for the desired alleles or genes, which are difficult to select based on phenotypic observations, such as pyramiding of disease and pest resistance genes in a specific genotype, where these may overlap each other's effect epistatically. Markers may be used for the selection of some progeny where recombination occurs near the targeted gene containing the allele with some DNA of the donor plant. These have a vital role in backcross breeding for the pyramiding of two or more genes linked with desired stresses tolerance [96]. Marker-assisted backcrossing gene pyramiding involves three levels of selection (Figure 3) [64,73]. Crossing is done between the recurrent parent and donor parents for the $F_{1}$ hybrid, which is then backcrossed up to three generations to obtain the best parent. It is further crossed with another donor parent for pyramiding two or more genes of interest. Although this technique is considered to have low satisfaction and also time consuming but, its precision for gene pyramiding, is considered good (Figure 3A) [97,98]. In other breeding techniques (Figure 3B), the recurrent parent is crossed with donor parents to obtain $F_{1}$ hybrids, and these are intercrossed to get improved $F_{1}$, which is further backcrossed with the recurrent parent to produce an improved recurrent parent. Thus, pyramiding is done in the pedigree itself. In the third strategy (Figure 3C), the first two schemes (Figure 3A,B) are combined; it involves simultaneous crossing of the recurrent parent with multiple donor parents, and then backcrossing up to the BC3 generation. The backcrossed populations are then intercrossed with each other to achieve gene pyramiding. This technique is considered most suitable, because it is less time consuming and fixation of genes is certain. However, success or failure of this technique depends on many factors, such as distance between the closest markers and the target gene, the number of target genes, the genetic base, the genetic background in which the target gene is manipulated, and the marker type. If proper selection criteria are maintained, then MABC-based gene pyramiding can produce durable and sustainable crop improvement [27,99-102].

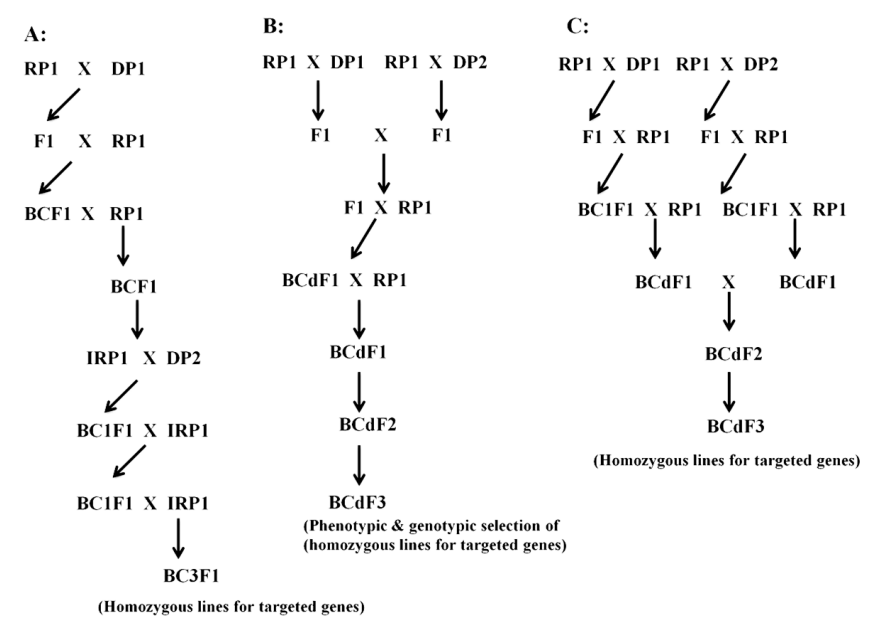

Figure 3. Schematic presentation of different backcrossing strategies for gene pyramiding. RP, recurrent parent; DP, donor parent; BC, backcross; IRP, improved recurrent parent; BCd, double backcross. (A): stepwise transfer. (B) simultaneous transfer. (C) simultaneous and stepwise transfer combined. In order to deliver a population of $\mathrm{BC} 1 \mathrm{~F} 1$, the $\mathrm{F}_{1}$ populations are crossed back to the $\mathrm{RP}$, and marker-assisted selection (MAS) is used to select resistance alleles. Then BC1F1 are backcrossed to $\mathrm{RP}$ to generate $\mathrm{BC} 2 \mathrm{~F} 1$, and selection is done through MAS. Among segregating populations, homozygous resistance genotypes are identified by MAS and BC2F1 and are backcrossed to RP to produce BC3F1 for greenhouse validation [73].

\subsection{Marker-Assisted Recurrent Selection}

Recurrent selection is considered an efficient approach for pyramiding multiple traits in plants; however, its efficacy of selection is not satisfactory, because phenotypic selection depends on environments, and genotypic selection takes much time (two to three cropping seasons for a cycle 
of selection) [103]. Marker-assisted recurrent selection (MARS) is an improved system that enables genotype selection and intercrossing in one cropping season (Figure 4), which can facilitate the efficacy of recurrent selection and expedite the selection process [104] and help in integration of multiple favorable genes. For complex agronomic traits, such as grain yield and biotic and abiotic stress resistance, the pyramiding of multiple QTLs into crops is recommended, and expression-QTL (eQTL), protein-QTL (pQTL), and metabolite-QTL (mQTL) types of analysis are applied on the multiple traits [83,105-107]. By sequencing the QTL region in several segregating lines, genotyping offers a rapid method for building high-resolution maps in a season to quicken positional cloning. Sequencing of each line within a recombinant inbred line (RIL) population has been used to easily and reliably classify recombinant breakpoints [108]. Therefore, a QTL peak was co-located with a GW5 gene (a major QTL on chromosome 5, qGW5) that regulates grain width [109]. Sequencing could target specific regions to identify the underlying QTL genes that control drought tolerance in wheat [110]. Expression-QTL, pQTL, or mQTL is linked with these traits. These intermediate molecular phenotypes help to reveal the genotypic variation and underlying morphological and physiological characteristics [111]. Mapping of eQTL patterns that regulate complex traits in the main regulatory regions can be defined and used in the molecular breeding of plants. Expression-QTLs reveal regions that affect gene expression in cis (close to the target gene itself, such as a promoter element) or in trans (distant to the gene). High eQTLs are normally cis-regulated; the eQTL position hence generally indicates the actual gene location [112]. The genes displaying differential expression between the recombinants can be genetically mapped to see if their position is related to the targeted QTLs. For instance, 88 genes that are differentially expressed during drought stress were linked with drought tolerance QTLs in maize and further selected as positional cloning candidates [113].

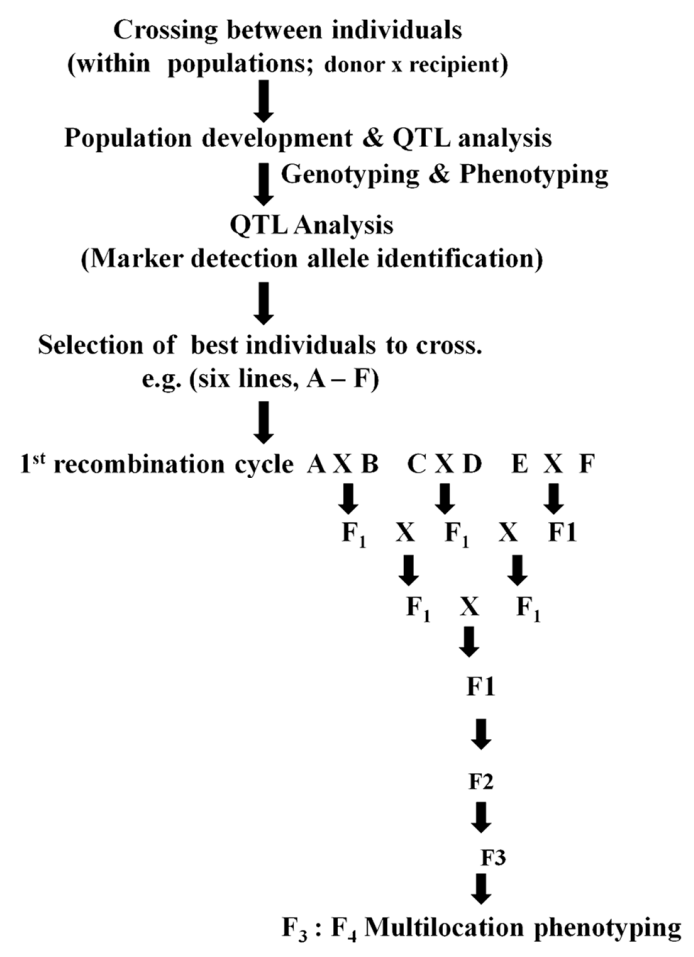

Figure 4. Schematic representation of marker-assisted recurrent selection in crops. Individual parents within the population were selected to cross to generate $F_{1}$ offspring. $F_{1}$ individuals were allowed selfing to produce $300 \mathrm{~F}_{2}$ progenies using the single-seed decent method. $\mathrm{F}_{2}$ individuals were advanced to $F_{3}, F_{4}$, and $F_{5}$. Genotyping was carried out on individual progenies. The best seeds were selected and evaluated in multi-location phenotyping. Qualitative trait loci (QTL) analysis was done and modeling was conducted prior to selection of QTLs for recombination. The six best genotypes per offspring of $\mathrm{F}_{3}$ were selected $(\mathrm{A}-\mathrm{F})$. The first recombination cycle generated $\mathrm{F}_{1}$ individuals, which were selfed to produce; $F_{2}$ and $F 2$ were advanced to $F_{3}$ and $F_{4}$ for multi-location phenotyping [27]. 
Many researchers have reported that the genetic advance obtained through MARS in maize was almost double as compared with phenotypic selection [106,114]. Bankole [115] also reported on the effectiveness of MARS for improvement of yield and related traits in maize. The basic procedure of MARS comprises some steps, such as selection of the parent lines from a similar and non-similar population [116]. Marker-assisted recurrent selection of $\mathrm{F}_{3}$-derived individuals is generally satisfactory and multiplied through a single-seed decent strategy for increasing seed to conduct multiplication trials. Large plant numbers are preferred to rely on the accuracy of QTL mapping. Further, QTL can be evaluated after geno-phenotypic analysis for the selection of markers and suitable alleles. The best population is selected for recombination, as shown in the example in Figure 4, where four genotypes are crossed to generate two pairs of $F_{1}$ offspring. At each cycle, genotyping is performed to identify the best $\mathrm{F}_{1}$ individuals, which could be used again in the next cycle of recombination [115].

\subsection{Omics Techniques for Crop Improvement}

Omics involves many techniques used to classify and measure the functions and relationships of broad collections of molecules of various types in an organism [117]. The technology includes transcriptomics (sequencing) [118,119], proteomics (structure and function of the proteins) [120-123], and metabolomics (detection and quantification in various biological organisms of metabolites and chemical signatures of cellular regulatory processes) [124-128] and enables seed profiling of gene transcription, protein expression, and/or small molecule synthesis and genome-level metabolism. Metabolomics is the innovative omics branch of science that identifies/quantifies the metabolites and chemical processes of the cellular regulatory system of the organisms. The metabolome is used to characterize genetic or environmental variations in any species and thus have a significant role in exploring environment and gene interactions, characterization of mutants, phenotyping, and biomarker identification. Thus, metabolomics is an innovative approach to be applied for exploration of various metabolic networks, linked with biotic and abiotic stress tolerance in plants and crop improvement [129]. Omics technology facilitates the rapid identification of nutritionally significant markers that may help to grow new, quality crops [130,131]. A key drawback of metabolomics is the lack of knowledge about several (secondary) metabolic pathways and reference standards in many of the metabolites (especially the myriad of secondary plant metabolites), and the inability to potentially classify the vast majority of synthesized metabolites in the plant kingdom [132]. Other problems associated with Omics technology are the cost of the technology for its direct application [128], and linkage of primary and secondary plant metabolites with very complex metabolic pathways. However, advanced metabolomics tools, such as gas chromatography mass spectrometry (GC-MS), liquid chromatography mass spectroscopy (LC-MS), and non-destructive nuclear magnetic resonance spectroscopy (NMR) allow the effective detection, identification, assessment, and evaluation of these metabolites [129]. Use of metabolic QTL-assisted breeding may lead to greater understanding of the function of specific genes of interest and their use for better screening and breeding of elite clones of crops [133-135].

\subsection{Marker-Assisted Gene Pyramiding in Developing Resistant Crop Varieties}

Gene stacking or pyramiding is a useful technique for transferring several desired genes or QTLs from different parents into a single genotype in the shortest possible time (two to three generations), as compared with conventional breeding, which takes a minimum of six generations to recuperate $99.2 \%$ of the recurrent parent genome [24,48]. It aims at accumulating several resistance genes with known effect on a trait of target and confers durable resistance against different stresses [88], and it became possible with recent advances in molecular markers techniques [136-138]. Plant scientists have successfully utilized this technique to pyramid resistant genes or QTLs through the help of closely associated markers against biotic stresses, such as late blight (Phytophthora infestans L.), bacterial blight (Xanthomonas campestris L.), gall midge (Contarinia quinquenotata L.), mosaic viruses, powdery mildew (Podosphaera xanthii L.), and many abiotic stresses, such as salinity, drought, heat, and cold, as well as quality improvement in many major crops, as shown in Table 1. Marker-assisted gene pyramiding 
also provides ease in selection of QTL allele-linked markers with similar phenotypic expression. Thus, pyramiding of several genes or QTLs is endorsed as a possible approach to improve quantitative as well as qualitative traits in plants $[72,85,139]$.

Marker-assisted selection facilitates the monitoring of several traits at a time, while separate field trials are required to screen for individual traits with traditional breeding method [44]. Moreover, MAS facilitates cost-effective gene stacking by selecting desirable plants at the initial stage of growth, which greatly reduces field space, maintenance cost of germplasm, and cost of agronomic inputs for field trials. When several genes conferring resistance to similar stresses are assembled, the markers are potent and effective for classifying those plants bearing genes of interest from undesirable ones [140]. It could be inferred undoubtedly that marker-assisted gene pyramiding is quick, proficient, economical, and a simple technique for application in plant breeding to pyramid genes of interest to build up multiple stress tolerances in crops [72,84,140,141].

\subsection{Gene Pyramiding Involving Polygenic Applications}

Many quantitative traits, such as yield and quality, along with tolerance to biotic and abiotic stresses have great economic value. Genetic expression affecting these traits is normally regulated by a large number of loci that have some impact on the development of phenotypic traits. These loci (QTLs) can be manipulated by molecular markers as Mendelian entities to harbor resistance against stresses and to improve many quantitative and qualitative traits [142-144]. Marker-assisted selection has been used successfully in polygenic trait development in many crop plants with a high level of success through genotype and pedigree selection and introgression of alien genes in elite lines using advanced backcrossed inbred selection [145]. However, polygenic traits related with yield improvement pose some complications, because yield trait selection is done by crossing between the best lines from a pool. Hence, QTLs mapped in one population may have low significance for other populations. Genetic improvement using the advanced backcross quantitative trait loci (AB-QTL) technique has been utilized for many important traits, such as fruit quality improvement and fungus (mold) resistance in tomato [146]. The advances made in the utilization of gene pyramiding techniques to improve the yield, quality, and stress tolerance in many crops are summarized in Table 1.

Table 1. Gene pyramiding for biotic, abiotic stresses, and quality improvements in crops.

\begin{tabular}{|c|c|c|c|}
\hline Crop & Traits & Pyramided Genes & References \\
\hline \multicolumn{4}{|c|}{ Biotic stress tolerance } \\
\hline Potato & Late blight resistance & Rpi-phu 1, Rpi-rzc & [147] \\
\hline \multirow[t]{4}{*}{ Cotton } & Bacterial blight/sheath resistance & Chi11, t1p, Xa21 & [148] \\
\hline & Bollworm resistance & $C r y 1 A c, C r y 2 A b$ & [149] \\
\hline & Weed and pathogen resistance & $p t x D / P h i$ & [6] \\
\hline & Insect pest resistance & Cry $1 A c, C r y 2 A c$ & [150] \\
\hline \multirow[t]{3}{*}{ Wheat } & Leaf and stem rust resistance & SrCad, Sr33, Lr34, Fhb & [151] \\
\hline & Cereal cyst nematode resistance & CreX, CreY, CRISPR-Cas9 & [152] \\
\hline & Aphid resistance & $G n 2, G n 4$ & [153] \\
\hline \multirow[t]{5}{*}{ Rice } & Gall midge resistance & $G m 1, G m 2, G m 4$ & [75] \\
\hline & Blast resistance & Pi(2)t, Pi25, Pi(t)a, Xa4, Xa5, Xa13, Xa21 & {$[154,155]$} \\
\hline & $\mathrm{BPH}$ resistance & Bph1, Bph2 & [156] \\
\hline & Blight resistance & Xa5, Xa13, Xa21 & [157] \\
\hline & Bacterial, sheath blight, stem borer & Xa12, Rc7, Cry1AB1, Cry14c & [158] \\
\hline Soybean & Mosaic virus resistance & $R s v 1, R s v 3, R s v 4$ & [30] \\
\hline Tomato & Leaf curl/spotted virus & $T y-1, T y-3, S w-5$ & [159] \\
\hline \multirow[t]{2}{*}{ Barley } & Mosaic virus resistance & rym4, rym5, rym9, rym11 & [160] \\
\hline & Strip rust resistance & $3 Q T L$ & [161] \\
\hline Com & Com borer resistance & Cry1le, Cry1Ac & [162] \\
\hline
\end{tabular}


Table 1. Cont.

\begin{tabular}{llll}
\hline \multicolumn{1}{c}{ Crop } & \multicolumn{1}{c}{ Traits } & \multicolumn{1}{c}{ Pyramided Genes } & References \\
\hline Chickpea & Lepidopteran resistance & Cry1Ac, Cry1Ab & {$[163]$} \\
\hline Pepper & Root-knot nematode resistance & Me1, Me2 & {$[164]$} \\
\hline Abiotic stress tolerance & & {$[165]$} \\
\hline Rice & Cold tolerance & 9PssT-3, 9PssT-7, 9PssT9, & {$[166]$} \\
& Cold tolerance & $9 S C T 1 a, 9 S C T 2$ & {$[75]$} \\
& Drought tolerance & Soltol & {$[167]$} \\
& Drought tolerance & QTLs & {$[168]$} \\
& Cold tolerance & $q P S S T-3, q P S S T-7, q P S S T-9$, qSCT1, TSF4-1 & {$[169]$} \\
\hline Quantitative and qualitative traits & OsHSP18.6 & {$[170]$} \\
\hline Cereal & High yield & Gn1a/OsCKX2, APO1, WFP/OsSPL 14 & {$[170]$} \\
\hline
\end{tabular}

\section{Challenges in Molecular Markers Utilization in Plant Breeding}

A major challenge of using molecular markers in plant breeding is the high cost to secure and maintain molecular laboratories [88]. There is a huge initial capital cost requirement for marker development, and it is one of the main limitations in marker use in many developing countries for crop improvement [171]. Constant electric supply to preserve the markers at a very low temperature is another major constraint. Additionally, using MAS for line development lacks consistency in determining phenotypes of crops, and bias sampling from a small population may be misleading for specific expression [172,173]. Recombination is another problem, which may occur during DNA replication, because during the recombination process, someone may not be sure about the exact marker option that is linked to an individual gene or allele. Markers are categorized as direct (within major gene) or indirect markers (near major gene), and recombination is the function of the distance between a gene or QTL and the linked marker. It is undesirable for recombination with higher distance between a maker and a major gene [174-176].

Quantitative trait loci mapping is based on the concept of population mapping for the presence or absence of different locus markers and the identification of markers capable of differentiating quantitative traits among the population. The effective recognition of the target hybrid depends on the parents selected and the gene effects involved in the trait expression [177]. Most economic traits of many crops are complex and regulated by multiple genes, each having its own effect; hence, MAS application also has some limitations in the breeding of desired characteristics. Plant breeding is also referred to as applied quantitative genetics, and modern quantitative genetic tools are expediting crop improvement through combining linked and unlinked genes [178-180]. The inclusion of genome-wide markers is needed to overcome these problems. Genomic selection (GS) is an upgraded version of MAS aimed at applying approximate genome-wide markers of all loci and measuring the estimated genomic breeding value (EGBV) to achieve more precise and consistent selection. Genetic selection has opened up a new promising era for research into molecular breeding, and quantitative genetics can be extended to association mapping between markers and phenotypes considering marker and phenotypic knowledge of populations, but in GS models, there is a problem of higher markers than the number of phenotypic observations [178]. Recent advances in breeding for quantitative trait selection, involving high-throughput genotyping and phenotyping events, whole genome sequence (WGS), high recombination ratios, and other advancements, such as speed breeding in quantitative genetics, have allowed scientists to better understand quantitative traits and accelerate the crop improvement process [179]. High-throughput genotyping and phenotyping using spectral reflectance/absorbance, thermography, optical imaging, and platforms/methodologies for root system analysis and trait selection with high accuracy and crop improvement can be accelerated by the new innovation of "speed 
breeding", through shortening the life cycle of plants with a controlled temperature and enhanced photoperiod [181,182]. Successful adoption of quantitative genetic tools, such as doubled haploid growth, MAS, genetic mapping, genomic selection, high-throughput genotyping/phenotyping, reverse, transgenic, shuttle and speed breeding, and genome editing may be used for desired gene pyramiding and early release of crop varieties resistant to biotic and abiotic stress with improved qualitative and quantitative traits [182]. Application of population genomics is based on the identification of outlier loci, screening large numbers of anonymous loci, and comparing statistics between candidate genes and a random sample of unlinked loci without considering the possible selective agent and the ecological context in which selection occurs [183-185]. Some models and algorithms, such as machine learning and genomic best linear unbiased prediction (GBLUP) are being applied for genomic selection to improve prediction accuracy and overcome this problem [185].

\section{Contribution of the Gene Pyramiding Technique to Agricultural Sustainability}

The gene pyramiding technique has contributed enormously to modern agriculture. It has led to tolerance development in plants for diseases, insect pests, and abiotic stresses and productivity enhancement on a sustainable basis. Molecular markers have made it possible for quick and precise plant breeding and early generation selection for significant traits without extensive field research. Gene pyramiding, through MAS, has enabled the integration of multiple genes into a single plant to achieve the goals of biotic or abiotic stress resistance and a higher yield with the desired nutritional quality. Durability of biotic and abiotic tolerance is crucial for sustainably achieving global food requirements. Many researchers have reported on the successful pyramiding and function of resistance genes into crops to increase the durable resistance against different insect pests and pathogens. An overview of gene pyramiding in major important crop species has been presented in Table 1 . The utilization of host plant resistance is economically viable, durable, and environmentally friendly option for overcoming biotic and abiotic stresses. In most of the cases, biotic resistance developed by a single gene is shaken within a short period of time, so modern breeding techniques are focusing at pyramiding of several genes or QTLs into a single genotype to insure long-lasting resistance for sustainable crop production $[50,95,186]$.

\section{Conclusions}

There are several stresses that cause devastating effects on the productivity and cultivation of crops throughout the globe. To fulfill the needs of the world's growing population for food, there is an immense need to safeguard crop plants from biotic and abiotic stresses, which cause yield and quality losses. In the present era, conventional plant breeding has improved with the help of molecular markers and MAS strategies. Many stress-tolerant genes have been integrated into crop plants for higher yield, durable stress resistance/tolerance, and enhanced nutritional traits. Molecular marker genotyping has simplified the breeding selection process and reduced the number of generations required for evaluation and gene integration into a desired cultivar. Marker-assisted selection gene pyramiding should be fully explored to minimize the risk of crop yield and quality reduction due to biotic and abiotic stresses. This strategy has already been utilized successfully for accumulation of several resistant/tolerant genes in some varieties of potato, rice, wheat, and barley. The field results are encouraging for stress tolerance and yield performance. Despite the tremendous advancement of gene pyramiding, there are still challenges that need to be addressed to improve its implementation and vast impact. Marker-assisted gene pyramiding should be cost effective, and technical collaboration and financial support make this more viable for developing counties to use for improvement of their local germplasm. Successful accumulation of resistant genes has been accomplished in the areas of abiotic stress and disease resistance; however, there have only been small achievements in pest resistance and nutritional quality enhancement. Any innovation in a breeding program is measured on the contribution made towards improvement in crop production. Hence, breeders should take maximum 
advantage of MAS gene pyramiding, and it should be meritoriously implemented in breeding programs to achieve sustainable agricultural goals.

Author Contributions: R.D. and C.S. developed the research concept and wrote the original draft of the manuscript; K.A. assisted in the literature search, writing, and revision, J.A.C. contributed to the writing and review \& editing; Z.B. reviewed the manuscript; J.B. supervised the manuscript writing and funding acquisition. All authors have read and agreed to the published version of the manuscript.

Funding: This work has been supported by the National Natural Science Foundation of China (Grant No. 31660432), the Special Fund for Discipline Construction of Gansu Agricultural University (GAU-XKJS-2018-085, GAU-XKJS-2018-084), and the Gansu Provincial Key Laboratory of Aridland Crop Science, Gansu Agricultural University (Grant No. GSCS-2017-9).

Conflicts of Interest: The authors declare no conflict of interest.

\section{References}

1. Davis, K.F.; Chhatre, A.; Rao, N.D.; Singh, D.; Ghosh-Jerath, S.; Mridul, A.; Poblete-Cazenave, M.; Pradhan, N.; DeFries, R. Assessing the sustainability of post-Green Revolution cereals in India. Proc. Natl. Acad. Sci. USA 2019, 116, 25034-25041. [CrossRef] [PubMed]

2. Barrett, C.B. Measuring Food Insecurity. Science 2010, 327, 825-828. [CrossRef] [PubMed]

3. Atique, R.; Farooq, M.; Rashid, A.; Nadeem, F.; Stuerz, S.; Asch, F.; Bell, R.W.; Siddique, K.H.M. Boron nutrition of rice in different production systems: A review. Agron. Sustain. Dev. 2018, 38, 25. [CrossRef]

4. Mwobobia, E.G.; Sichangi, A.W.; Thiong'o, K.B. Characterization of wheat production using earth-based observations: A case study of Meru County, Kenya. Model. Earth Syst. Environ. 2020, 6, 13-25. [CrossRef]

5. Kage, U.; Kumar, A.; Dhokane, D.; Karre, S.; Kushalappa, A.C. Functional molecular markers for crop improvement. Crit. Rev. Biotechnol. 2016, 36, 917-930. [CrossRef]

6. Pandey, P.; Irulappan, V.; Bagavathiannan, M.V.; Senthil-Kumar, M. Impact of Combined Abiotic and Biotic Stresses on Plant Growth and Avenues for Crop Improvement by Exploiting Physio-morphological Traits. Front. Plant Sci. 2017, 8. [CrossRef]

7. Waddington, S.R.; Li, X.; Dixon, J.; Hyman, G.; de Vicente, M.C. Getting the focus right: Production constraints for six major food crops in Asian and African farming systems. Food Secur. 2010, 2, 27-48. [CrossRef]

8. Bowman, M.S.; Zilberman, D. Economic Factors Affecting Diversified Farming Systems. Ecol. Soc. 2013, 18. [CrossRef]

9. Belsky, J.; Joshi, N.K. Impact of Biotic and Abiotic Stressors on Managed and Feral Bees. Insects 2019, 10, 233. [CrossRef]

10. Choudhary, K.; Choudhary, O.P.; Shekhawat, N.S. Marker assisted selection: A novel approach for crop improvement. Am. Eurasian J. Agron. 2008, 1, 26-30.

11. Womack, E.D.; Williams, W.P.; Smith, J.S.; Warburton, M.L.; Bhattramakki, D. Mapping Quantitative Trait Loci for Resistance to Fall Armyworm (Lepidoptera: Noctuidae) Leaf-Feeding Damage in Maize Inbred Mp705. J. Econ. Entomol. 2020, 113, 956-963. [CrossRef]

12. Kansiime, M.K.; Mugambi, I.; Rwomushana, I.; Nunda, W.; Lamontagne-Godwin, J.; Rware, H.; Phiri, N.A.; Chipabika, G.; Ndlovu, M.; Day, R. Farmer perception of fall armyworm (Spodoptera frugiderda J.E. Smith) and farm-level management practices in Zambia. Pest Manag. Sci. 2019, 75, 2840-2850. [CrossRef]

13. Assefa, F. Status of Fall Armyworm (Spodoptera frugiperda), Biology and Control Measures on Maize Crop in Ethiopia: A Review. Int. J. Entomol. Res. 2018, 6. [CrossRef]

14. Nagoshi, R.N.; Goergen, G.; Tounou, K.A.; Agboka, K.; Koffi, D.; Meagher, R.L. Analysis of strain distribution, migratory potential, and invasion history of fall armyworm populations in northern Sub-Saharan Africa. Sci. Rep. 2018, 8, 3710. [CrossRef]

15. Sharifzadeh, M.S.; Abdollahzadeh, G.; Damalas, C.A.; Rezaei, R. Farmers' Criteria for Pesticide Selection and Use in the Pest Control Process. Agriculture 2018, 8, 24. [CrossRef]

16. Vincelli, P. Genetic Engineering and Sustainable Crop Disease Management: Opportunities for Case-by-Case Decision-Making. Sustainability 2016, 8, 495. [CrossRef]

17. Federico, A.C.; Darci, A.G.; Patrick, J.T. Empirical investigation of mutation rate for herbicide resistance. Weed Sci. 2019, 67, 361-368. 
18. Pandeya, D.; López-Arredondo, D.L.; Janga, M.R.; Campbell, L.M.; Estrella, H.P.; Bagavathiannan, M.V.; Herrera-Estrella, L.; Rathore, K.S. Selective fertilization with phosphite allows unhindered growth of cotton plants expressing the ptxD gene while suppressing weeds. Proc. Natl. Acad. Sci. USA 2018, 115, E6946-E6955. [CrossRef]

19. Hanson, P.; Lu, S.-F.; Wang, J.-F.; Chen, W.; Kenyon, L.; Tan, C.-W.; Tee, K.L.; Wang, Y.-Y.; Hsu, Y.-C.; Schafleitner, R.; et al. Conventional and molecular marker-assisted selection and pyramiding of genes for multiple disease resistance in tomato. Sci. Hortic. 2016, 201, 346-354. [CrossRef]

20. Mundt, C.C. Durable resistance: A key to sustainable management of pathogens and pests. Infect. Genet. Evol. 2014, 27, 446-455. [CrossRef]

21. Johnson, R. A Critical Analysis of Durable Resistance. Annu. Rev. Phytopathol. 1984, 22, 309-330. [CrossRef]

22. Kottapalli, K.R.; Lakshmi, N.M.; Jena, K.K. Effective strategy for pyramiding three bacterial blight resistance genes into fine grain rice cultivar, Samba Mahsuri, using sequence tagged site markers. Biotechnol. Lett. 2010, 32, 989-996. [CrossRef]

23. Steiner, B.; Michel, S.; Maccaferri, M.; Lemmens, M.; Tuberosa, R.; Buerstmayr, H. Exploring and exploiting the genetic variation of Fusarium head blight resistance for genomic-assisted breeding in the elite durum wheat gene pool. Theor. Appl. Genet. 2019, 132, 969-988. [CrossRef]

24. Suresh, S.; Malathi, D. Gene Pyramiding for Biotic Stress Tolerance In Crop plants. Wkly. Sci. Res. J. 2013, $1,1-14$.

25. Muthurajan, R.; Balasubramanian, P. Pyramiding Genes for Enhancing Tolerance to Abiotic and Biotic Stresses. In Molecular Techniques in Crop Improvement; Jain, S., Brar, D., Eds.; Springer: Dordrecht, The Netherlands, 2010.

26. Pancaldi, F.; Trindade, L.M. Marginal Lands to Grow Novel Bio-Based Crops: A Plant Breeding Perspective. Front. Plant Sci. 2020, 11. [CrossRef]

27. Rana, M.; Sood, A.; Hussain, W.; Kaldate, R.; Sharma, T.R.; Gill, R.K.; Kumar, S.; Singh, S. Chapter 6-Gene Pyramiding and Multiple Character Breeding. In Lentils; Singh, M., Ed.; Academic Press: Cambridge, MA, USA, 2019; pp. 83-124.

28. Bai, Y.; Kissoudis, C.; Yan, Z.; Visser, R.G.F.; van der Linden, G. Plant behaviour under combined stress: Tomato responses to combined salinity and pathogen stress. Plant J. 2018, 93, 781-793. [CrossRef]

29. Ruengphayak, S.; Chaichumpoo, E.; Phromphan, S.; Kamolsukyunyong, W.; Sukhaket, W.; Phuvanartnarubal, E.; Korinsak, S.; Korinsak, S.; Vanavichit, A. Pseudo-backcrossing design for rapidly pyramiding multiple traits into a preferential rice variety. Rice 2015, 8, 7. [CrossRef]

30. Zhu, S.; Li, Y.; Vossen, J.H.; Visser, R.G.F.; Jacobsen, E. Functional stacking of three resistance genes against Phytophthora infestans in potato. Transgenic Res. 2012, 21, 89-99. [CrossRef]

31. Piquerez, S.J.M.; Harvey, S.E.; Beynon, J.L.; Ntoukakis, V. Improving crop disease resistance: Lessons from research on Arabidopsis and tomato. Front. Plant Sci. 2014, 5, 671. [CrossRef]

32. Alconi, C.; Stevanato, P.; Motto, M.; Biancardi, E. Breeding for Biotic Stress Resistance/Tolerance in Plants. In Crop Production for Agricultural Improvement; Ashraf, M., Öztürk, M., Ahmad, M., Aksoy, A., Eds.; Springer: Dordrecht, The Netherlands, 2012.

33. Llorens, E.; González-Hernández, A.I.; Scalschi, L.; Fernández-Crespo, E.; Camañes, G.; Vicedo, B.; García-Agustín, P. Chapter 1-Priming mediated stress and cross-stress tolerance in plants: Concepts and opportunities. In Priming-Mediated Stress and Cross-Stress Tolerance in Crop Plants; Academic Press: Cambridge, MA, USA, 2020; pp. 1-20.

34. Yu, Y.; Yang, Z. The isolation and characterization of a putative dehydrin gene in Triticum aestivum L. Biochem. Syst. Ecol. 2016, 66, 173-180. [CrossRef]

35. Waqas, M.; Shahid, L.; Shoukat, K.; Aslam, U.; Azeem, F.; Atif, R.M. Chapter 1-Role of DNA-binding with one finger (Dof) transcription factors for abiotic stress tolerance in plants. In Transcription Factors for Abiotic Stress Tolerance in Plants; Academic Press: Cambridge, MA, USA, 2020; pp. 1-14.

36. Loo, Y.Y.; Billa, L.; Singh, A. Effect of climate change on seasonal monsoon in Asia and its impact on the variability of monsoon rainfall in Southeast Asia. Geosci. Front. 2015, 6, 817-823. [CrossRef]

37. Thitisaksakul, M.; Tananuwong, K.; Shoemaker, C.F.; Chun, A.; Tanadul, O.-U.-M.; Labavitch, J.M.; Beckles, D.M. Effects of Timing and Severity of Salinity Stress on Rice (Oryza sativa L.) Yield, Grain Composition, and Starch Functionality. J. Agric. Food Chem. 2015, 63, 2296-2304. [CrossRef] 
38. Tiwari, S.; Sl, K.; Kumar, V.; Singh, B.; Rao, A.R.; Mithra, S.A.; Rai, V.; Singh, A.K.; Singh, N.K. Mapping QTLs for Salt Tolerance in Rice (Oryza sativa L.) by Bulked Segregant Analysis of Recombinant Inbred Lines Using 50K SNP Chip. PLoS ONE 2016, 11, e0153610. [CrossRef]

39. Bimpong, I.K.; Manneh, B.; Sock, M.; Diaw, F.; Amoah, N.K.A.; Ismail, A.M.; Gregorio, G.; Singh, R.K.; Wopereis, M. Improving salt tolerance of lowland rice cultivar 'Rassi' through marker-aided backcross breeding in West Africa. Plant Sci. 2016, 242, 288-299. [CrossRef]

40. Ren, Z.-H.; Gao, J.-P.; Li, L.-G.; Cai, X.-L.; Huang, W.; Chao, D.-Y.; Zhu, M.-Z.; Wang, Z.-Y.; Luan, S.; Lin, H.-X. A rice quantitative trait locus for salt tolerance encodes a sodium transporter. Nat. Genet. 2005, 37, 1141-1146. [CrossRef]

41. Das, P.; Nutan, K.K.; Singla-Pareek, S.L.; Pareek, A. Understanding salinity responses and adopting 'omics-based' approaches to generate salinity tolerant cultivars of rice. Front. Plant Sci. 2015, 6, 712. [CrossRef]

42. Oladosu, Y.; Rafii, M.Y.; Samuel, C.; Fatai, A.; Magaji, U.; Kareem, I.; Kamarudin, Z.S.; Muhammad, I.; Kolapo, K. Drought Resistance in Rice from Conventional to Molecular Breeding: A Review. Int. J. Mol. Sci. 2019, 20, 3519. [CrossRef]

43. Sandhu, N.; Dixit, S.; Swamy, B.P.M.; Raman, A.; Kumar, S.; Singh, S.P.; Yadaw, R.B.; Singh, O.N.; Reddy, J.N.; Anandan, A.; et al. Marker Assisted Breeding to Develop Multiple Stress Tolerant Varieties for Flood and Drought Prone Areas. Rice 2019, 12, 8. [CrossRef]

44. Rai, N.; Bellundagi, A.; Kumar, P.K.C.; Kalasapura, T.R.; Rani, S.; Sinha, N.; krishna, H.; Jain, N.; Singh, G.P.; Singh, P.K.; et al. Marker-assisted backcross breeding for improvement of drought tolerance in bread wheat (Triticum aestivum L. em Thell). Plant Breed. 2018, 137, 514-526. [CrossRef]

45. Zhang, H.; Zhang, J.; Wei, P.; Zhang, B.; Gou, F.; Feng, Z.; Mao, Y.; Yang, L.; Zhang, H.; Xu, N.; et al. The CRISPR/Cas9 system produces specific and homozygous targeted gene editing in rice in one generation. Plant Biotechnol. J. 2014, 12, 797-807. [CrossRef]

46. Shinada, H.; Iwata, N.; Sato, T.; Fujino, K. QTL pyramiding for improving of cold tolerance at fertilization stage in rice. Breed. Sci. 2014, 63, 483-488. [CrossRef]

47. Almeida, D.M.; Almadanim, M.C.; Lourenço, T.; Abreu, I.A.; Saibo, N.J.; Oliveira, M.M. Screening for Abiotic Stress Tolerance in Rice: Salt, Cold, and Drought. Methods Mol. Biol. 2016, 1398, 155-182. [CrossRef]

48. Hasan, M.M.; Rafii, M.Y.; Ismail, M.R.; Mahmood, M.; Rahim, H.A.; Alam, M.A.; Ashkani, S.; Malek, M.A.; Latif, M.A. Marker-assisted backcrossing: A useful method for rice improvement. Biotechnol. Biotechnol. Equip. 2015, 29, 237-254. [CrossRef]

49. Sanghera, G.S.; Wani, S.H.; Hussain, W.; Singh, N.B. Engineering cold stress tolerance in crop plants. Curr. Genom. 2011, 12, 30-43. [CrossRef]

50. Lv, H.; Fang, Z.; Yang, L.; Zhang, Y.; Wang, Y. An update on the arsenal: Mining resistance genes for disease management of Brassica crops in the genomic era. Hortic. Res. 2020, 7, 34. [CrossRef]

51. Van Esse, H.P.; Reuber, T.L.; van der Does, D. Genetic modification to improve disease resistance in crops. New Phytol. 2020, 225, 70-86. [CrossRef]

52. Borrelli, V.M.G.; Brambilla, V.; Rogowsky, P.; Marocco, A.; Lanubile, A. The Enhancement of Plant Disease Resistance Using CRISPR/Cas9 Technology. Front. Plant Sci. 2018, 9, 1245. [CrossRef]

53. Sedeek, K.E.M.; Mahas, A.; Mahfouz, M. Plant Genome Engineering for Targeted Improvement of Crop Traits. Front. Plant Sci. 2019, 10. [CrossRef]

54. Kah, M.; Tufenkji, N.; White, J.C. Nano-enabled strategies to enhance crop nutrition and protection. Nat. Nanotechnol. 2019, 14, 532-540. [CrossRef]

55. Bailey-Serres, J.; Parker, J.E.; Ainsworth, A.; Oldroyd, G.E.D.; Schroeder, J.I. Genetic strategies for improving crop yields. Nature 2019, 575, 109-118. [CrossRef]

56. Fuchs, M. Pyramiding resistance-conferring gene sequences in crops. Curr. Opin. Virol. 2017, 26, 36-42. [CrossRef]

57. Liu, R.; Lu, J.; Zhou, M.; Zheng, S.; Liu, Z.; Zhang, C.; Du, M.; Wang, M.; Li, Y.; Wu, Y.; et al. Developing stripe rust resistant wheat (Triticum aestivum $\mathrm{L}$.) lines with gene pyramiding strategy and marker-assisted selection. Genet. Resour. Crop Evol. 2020, 67, 381-391. [CrossRef]

58. Ashkani, S.; Rafii, M.Y.; Shabanimofrad, M.; Miah, G.; Sahebi, M.; Azizi, P.; Tanweer, F.A.; Akhtar, M.S.; Nasehi, A. Molecular Breeding Strategy and Challenges Towards Improvement of Blast Disease Resistance in Rice Crop. Front. Plant Sci. 2015, 6, 886. [CrossRef] 
59. Srivastava, V.; Thomson, J. Gene stacking by recombinases. Plant Biotechnol. J. 2016, 14, 471-482. [CrossRef]

60. Gupta, S.K.; Pandey, M.K. Chapter 19-Breeding for Disease and Insect-Pest Resistance. In Integrated Pest Management; Abrol, D.P., Ed.; Academic Press: San Diego, CA, USA, 2014; pp. 401-417.

61. Mago, R.; Lawrence, G.J.; Ellis, J.G. The application of DNA marker and doubled-haploid technology for stacking multiple stem rust resistance genes in wheat. Mol. Breed. 2011, 27, 329-335. [CrossRef]

62. Liu, J.; Liu, D.; Tao, W.; Li, W.; Wang, S.; Chen, P.; Cheng, S.; Gao, D. Molecular marker-facilitated pyramiding of different genes for powdery mildew resistance in wheat. Plant Breed. 2000, 119, 21-24. [CrossRef]

63. Nelson, R.; Wiesner-Hanks, T.; Wisser, R.; Balint-Kurti, P. Navigating complexity to breed disease-resistant crops. Nat. Rev. Genet. 2018, 19, 21-33. [CrossRef]

64. Pathania, A.; Rialch, N.; Sharma, P.N. Marker-Assisted Selection in Disease Resistance Breeding: A Boon to Enhance Agriculture Production. In Current Developments in Biotechnology and Bioengineering; Dubey, S.K., Pandey, A., Sangwan, R.S., Eds.; Elsevier: Amsterdam, The Netherlands, 2017; pp. 187-213.

65. Dixit, S.; Singh, U.M.; Singh, A.K.; Alam, S.; Venkateshwarlu, C.; Nachimuthu, V.V.; Yadav, S.; Abbai, R.; Selvaraj, R.; Devi, M.N.; et al. Marker Assisted Forward Breeding to Combine Multiple Biotic-Abiotic Stress Resistance/Tolerance in Rice. Rice 2020, 13, 29. [CrossRef]

66. Floros, J.D.; Newsome, R.; Fisher, W.; Barbosa-Cánovas, G.V.; Chen, H.; Dunne, C.P.; German, J.B.; Hall, R.L.; Heldman, D.R.; Karwe, M.V.; et al. Feeding the World Today and Tomorrow: The Importance of Food Science and Technology. Compr. Rev. Food Sci. Food Saf. 2010, 9, 572-599. [CrossRef]

67. Su, J.; Jiang, J.; Zhang, F.; Liu, Y.; Ding, L.; Chen, S.; Chen, F. Current achievements and future prospects in the genetic breeding of chrysanthemum: A review. Hortic. Res. 2019, 6, 109. [CrossRef]

68. Zhang, Y.; Massel, K.; Godwin, I.D.; Gao, C. Applications and potential of genome editing in crop improvement. Genome Biol. 2018, 19, 210. [CrossRef] [PubMed]

69. Malav, A.K.; Chandrawat, K.S.I. Gene pyramiding: An overview. Int. J. Curr. Res. Biosci. Plant Biol. 2016, 3, 22-28. [CrossRef]

70. Hall, L.M.; Booker, H.; Siloto, R.M.P.; Jhala, A.J.; Weselake, R.J. Chapter 6-Flax (Linum usitatissimum L.). In Industrial Oil Crops; McKeon, T.A., Hayes, D.G., Hildebrand, D.F., Weselake, R.J., Eds.; AOCS Press: Urbana, IL, USA, 2016; pp. 157-194.

71. Cui, Y.; Patel, J.; Zou, J.; Keller, W.A. Oilseed Brassicas. In Compendium Transgenic Crop Plants; Kole, C., Hall, T.C., Eds.; Wiley-Blackwell: Hoboken, NJ, USA, 2009.

72. Moose, S.P.; Mumm, R.H. Molecular Plant Breeding as the Foundation for 21st Century Crop Improvement. Plant Physiol. 2008, 147, 969-977. [CrossRef] [PubMed]

73. Joshi, R.K.; Nayak, S. Gene pyramiding-A broad spectrum technique for developing durable stress resistance in crops. Biotechnol. Mol. Biol. Rev. 2010, 5, 51-60.

74. Miah, G.; Rafii, M.Y.; Ismail, M.R.; Puteh, A.B.; Rahim, H.A.; Islam, K.N.; Latif, M.A. A review of microsatellite markers and their applications in rice breeding programs to improve blast disease resistance. Int. J. Mol. Sci. 2013, 14, 22499-22528. [CrossRef]

75. Das, G.; Rao, G.J.N. Molecular marker assisted gene stacking for biotic and abiotic stress resistance genes in an elite rice cultivar. Front. Plant Sci. 2015, 6, 698. [CrossRef]

76. Hayashi, K.; Hashimoto, N.; Daigen, M.; Ashikawa, I. Development of PCR-based SNP markers for rice blast resistance genes at the Piz locus. Theor. Appl. Genet. 2004, 108, 1212-1220. [CrossRef]

77. Liu, W.; Maurer, H.P.; Li, G.; Tucker, M.R.; Gowda, M.; Weissmann, E.A.; Hahn, V.; Würschum, T. Genetic architecture of winter hardiness and frost tolerance in triticale. PLoS ONE 2014, 9, e99848. [CrossRef]

78. Tullu, A.; Tar'an, B.; Warkentin, T.; Vandenberg, A. Construction of an Intraspecific Linkage Map and QTL Analysis for Earliness and Plant Height in Lentil. Crop Sci. 2008, 48, 2254-2264. [CrossRef]

79. Taylor, P.W.J.; Ades, P.K.; Ford, R. QTL mapping of resistance in lentil (Lens culinaris ssp. culinaris) to ascochyta blight (Ascochyta lentis). Plant Breed. 2006, 125, 506-512. [CrossRef]

80. Fedoruk, M.J.; Vandenberg, A.; Bett, K.E. Quantitative Trait Loci Analysis of Seed Quality Characteristics in Lentil using Single Nucleotide Polymorphism Markers. Plant Genome 2013, 6. [CrossRef]

81. Van Eeuwijk, F.A.; Bustos-Korts, D.; Millet, E.J.; Boer, M.P.; Kruijer, W.; Thompson, A.; Malosetti, M.; Iwata, H.; Quiroz, R.; Kuppe, C.; et al. Modelling strategies for assessing and increasing the effectiveness of new phenotyping techniques in plant breeding. Plant Sci. 2019, 282, 23-39. [CrossRef]

82. Ahmed, M.M.; Huang, C.; Shen, C.; Khan, A.Q.; Lin, Z. Map-based cloning of qBWT-c12 discovered brassinosteroid-mediated control of organ size in cotton. Plant Sci. 2020, 291, 110315. [CrossRef] [PubMed] 
83. Ribaut, J.M.; de Vicente, M.C.; Delannay, X. Molecular breeding in developing countries: Challenges and perspectives. Curr. Opin. Plant Biol. 2010, 13, 213-218. [CrossRef]

84. Collard, B.C.Y.; Mackill, D.J. Marker-assisted selection: An approach for precision plant breeding in the twenty-first century. Philos. Trans. R. Soc. Lond. B Biol. Sci. 2008, 363, 557-572. [CrossRef] [PubMed]

85. Chukwu, S.C.; Rafii, M.Y.; Ramlee, S.I.; Ismail, S.I.; Hasan, M.M.; Oladosu, Y.A.; Magaji, U.G.; Akos, I.; Olalekan, K.K. Bacterial leaf blight resistance in rice: A review of conventional breeding to molecular approach. Mol. Biol. Rep. 2019, 46, 1519-1532. [CrossRef] [PubMed]

86. Oladosu, Y.; Rafii, M.Y.; Magaji, U.; Abdullah, N.; Miah, G.; Chukwu, S.C.; Hussin, G.; Ramli, A.; Kareem, I. Genotypic and Phenotypic Relationship among Yield Components in Rice under Tropical Conditions. Biomed Res. Int. 2018, 2018, 8936767. [CrossRef]

87. Quibod, I.L.; Perez-Quintero, A.; Booher, N.J.; Dossa, G.S.; Grande, G.; Szurek, B.; Vera Cruz, C.; Bogdanove, A.J.; Oliva, R. Effector Diversification Contributes to Xanthomonas oryzae pv. oryzae Phenotypic Adaptation in a Semi-Isolated Environment. Sci. Rep. 2016, 6, 34137. [CrossRef]

88. Das, G.; Patra, J.K.; Baek, K.-H. Insight into MAS: A Molecular Tool for Development of Stress Resistant and Quality of Rice through Gene Stacking. Front. Plant Sci. 2017, 8. [CrossRef]

89. Poczai, P.; Varga, I.; Laos, M.; Cseh, A.; Bell, N.; Valkonen, J.P.T.; Hyvönen, J. Advances in plant gene-targeted and functional markers: A review. Plant Methods 2013, 9, 6. [CrossRef]

90. Wang, Z.; Baulcombe, D.C. Transposon age and non-CG methylation. Nat. Commun. 2020, 11, 1221. [CrossRef] [PubMed]

91. Shirasawa, K.; Hirakawa, H. DNA marker applications to molecular genetics and genomics in tomato. Breed. Sci. 2013, 63, 21-30. [CrossRef] [PubMed]

92. Bohle, H.M.; Gabaldón, T. Selection of marker genes using whole-genome DNA polymorphism analysis. Evol. Bioinform. Online 2012, 8, 161-169. [CrossRef] [PubMed]

93. Nadeem, M.A.; Nawaz, M.A.; Shahid, M.Q.; Doğan, Y.; Comertpay, G.; Yıldız, M.; Hatipoğlu, R.; Ahmad, F.; Alsaleh, A.; Labhane, N.; et al. DNA molecular markers in plant breeding: Current status and recent advancements in genomic selection and genome editing. Biotechnol. Biotechnol. Equip. 2018, 32, $261-285$. [CrossRef]

94. Tong, H.; Küken, A.; Nikoloski, Z. Integrating molecular markers into metabolic models improves genomic selection for Arabidopsis growth. Nat. Commun. 2020, 11, 2410. [CrossRef]

95. Pilet-Nayel, M.-L.; Moury, B.; Caffier, V.; Montarry, J.; Kerlan, M.-C.; Fournet, S.; Durel, C.-E.; Delourme, R. Quantitative Resistance to Plant Pathogens in Pyramiding Strategies for Durable Crop Protection. Front. Plant Sci. 2017, 8, 1838. [CrossRef]

96. Ye, Y.; Cai, M.; Ju, Y.; Jiao, Y.; Feng, L.; Pan, H.; Cheng, T.; Zhang, Q. Identification and Validation of SNP Markers Linked to Dwarf Traits Using SLAF-Seq Technology in Lagerstroemia. PLoS ONE 2016, 11, e0158970. [CrossRef]

97. Kushwah, A.; Gupta, S.; Bindra, S.; Johal, N.; Singh, I.; Bharadwaj, C.; Dixit, G.P.; Gaur, P.M.; Nayyar, H.; Singh, S. Chapter 6-Gene pyramiding and multiple character breeding. In Chickpea: Crop Wild Relatives for Enhancing Genetic Gains; Academic Press: Cambridge, MA, USA, 2020; pp. 131-165.

98. Pazhamala, L.; Saxena, R.K.; Singh, V.K.; Sameerkumar, C.V.; Kumar, V.; Sinha, P.; Patel, K.; Obala, J.; Kaoneka, S.R.; Tongoona, P.; et al. Genomics-assisted breeding for boosting crop improvement in pigeonpea (Cajanus cajan). Front. Plant Sci. 2015, 6, 50. [CrossRef]

99. Hu, J.; Xiao, C.; He, Y. Recent progress on the genetics and molecular breeding of brown planthopper resistance in rice. Rice 2016, 9, 30. [CrossRef]

100. Jiang, G.L. Molecular Marker-Assisted Breeding: A Plant Breeder's Review. In Advances in Plant Breeding Strategies: Breeding, Biotechnology and Molecular Tools; Al-Khayri, J., Jain, S., Johns, D., Eds.; Springer: Cham, Switzerland, 2015.

101. Panigrahi, J.; Mishra, R.R.; Sahu, A.R.; Rath, S.C.; Kole, C.R. Marker-Assisted Breeding for Stress Resistance in Crop Plants. In Advances in Plant Breeding Strategies: Breeding, Biotechnology and Molecular Tools; Al-Khayri, J., Jain, S., Johnson, D., Eds.; Springer: Cham, Switzerland, 2013.

102. Rezene, Y.; Tesfaye, K.; Mukankusi, C.; Gepts, P. Marker-Assisted Pyramiding Resistance Genes Against Angular Leaf Spot and Common Bacterial Blight Disease into Preferred Common Bean Cultivar "REDWOLAITA". Adv. Crop Sci. Technol. 2019, 7, 416. [CrossRef] 
103. Jiang, W.; Zhou, H.; Bi, H.; Fromm, M.; Yang, B.; Weeks, D.P. Demonstration of CRISPR/Cas9/sgRNA-mediated targeted gene modification in Arabidopsis, tobacco, sorghum and rice. Nucleic Acids Res. 2013, 41, e188. [CrossRef] [PubMed]

104. Cai, J.; Wang, S.; Su, Z.; Li, T.; Zhang, X.; Bai, G. Meta-analysis of QTL for Fusarium head blight resistance in Chinese wheat landraces. Crop J. 2019, 7, 784-798. [CrossRef]

105. Almeida, G.D.; Makumbi, D.; Magorokosho, C.; Nair, S.; Borém, A.; Ribaut, J.-M.; Bänziger, M.; Prasanna, B.M.; Crossa, J.; Babu, R. QTL mapping in three tropical maize populations reveals a set of constitutive and adaptive genomic regions for drought tolerance. Theor. Appl. Genet. 2013, 126, 583-600. [CrossRef] [PubMed]

106. Crosbie, T.M.; Eathington, S.R.; Johnson, G.R.; Edwards, M.; Reiter, R.; Stark, S.; Mohanty, R.G.; Oyervides, M.; Buehler, R.E.; Walker, A.K.; et al. Plant Breeding: Past, Present, and Future. In Plant Breeding: The Arnel R. Hallauer International Symposium; Lamkey, K.R., Lee, M., Eds.; Wiley-Blackwell: Hoboken, NJ, USA, 2006.

107. Gu, R.; Chen, F.; Long, L.; Cai, H.; Liu, Z.; Yang, J.; Wang, L.; Li, H.; Li, J.; Liu, W.; et al. Enhancing phosphorus uptake efficiency through QTL-based selection for root system architecture in maize. J. Genet. Genom. 2016, 43, 663-672. [CrossRef]

108. Huang, X.; Feng, Q.; Qian, Q.; Zhao, Q.; Wang, L.; Wang, A.; Guan, J.; Fan, D.; Weng, Q.; Huang, T.; et al. High-throughput genotyping by whole-genome resequencing. Genome Res. 2009, 19, 1068-1076. [CrossRef]

109. Xie, W.; Feng, Q.; Yu, H.; Huang, X.; Zhao, Q.; Xing, Y.; Yu, S.; Han, B.; Zhang, Q. Parent-independent genotyping for constructing an ultrahigh-density linkage map based on population sequencing. Proc. Natl. Acad. Sci. USA 2010, 107, 10578-10583. [CrossRef]

110. Burbano, H.A.; Hodges, E.; Green, R.E.; Briggs, A.W.; Krause, J.; Meyer, M.; Good, J.M.; Maricic, T.; Johnson, P.L.F.; Xuan, Z.; et al. Targeted Investigation of the Neandertal Genome by Array-Based Sequence Capture. Science 2010, 328, 723-725. [CrossRef]

111. Potokina, E.; Druka, A.; Luo, Z.; Wise, R.; Waugh, R.; Kearsey, M. Gene expression quantitative trait locus analysis of 16,000 barley genes reveals a complex pattern of genome-wide transcriptional regulation. Plant $J$. 2008, 53, 90-101. [CrossRef]

112. Druka, A.; Druka, I.; Centeno, A.G.; Li, H.; Sun, Z.; Thomas, W.T.B.; Bonar, N.; Steffenson, B.J.; Ullrich, S.E.; Kleinhofs, A.; et al. Towards systems genetic analyses in barley: Integration of phenotypic, expression and genotype data into GeneNetwork. BMC Genet. 2008, 9, 73. [CrossRef]

113. Marino, R.; Ponnaiah, M.; Krajewski, P.; Frova, C.; Gianfranceschi, L.; Pè, M.E.; Sari-Gorla, M. Addressing drought tolerance in maize by transcriptional profiling and mapping. Mol. Genet. Genom. 2009, 281, 163-179. [CrossRef]

114. Ribaut, J.-M.; Ragot, M. Marker-assisted selection to improve drought adaptation in maize: The backcross approach, perspectives, limitations, and alternatives. J. Exp. Bot. 2006, 58, 351-360. [CrossRef] [PubMed]

115. Bankole, F.; Menkir, A.; Olaoye, G.; Crossa, J.; Hearne, S.; Unachukwu, N.; Gedil, M. Genetic Gains in Yield and Yield Related Traits under Drought Stress and Favorable Environments in a Maize Population Improved Using Marker Assisted Recurrent Selection. Front. Plant Sci. 2017, 8. [CrossRef] [PubMed]

116. Ali, M.; Zhang, L.; DeLacy, I.; Arief, V.; Dieters, M.; Pfeiffer, W.H.; Wang, J.; Li, H. Modeling and simulation of recurrent phenotypic and genomic selections in plant breeding under the presence of epistasis. Crop J. 2020. [CrossRef]

117. EFSA(European-Food-sqafety-Authority); Aguilera, J.; Aguilera-Gomez, M.; Barrucci, F.; Cocconcelli, P.S.; Davies, H.; Denslow, N.; Dorne, J.L.; Grohmann, L. EFSA Scientific Colloquium 24-'omics in risk assessment: State of the art and next steps. EFSA Support. Publ. 2018, 15, 1512. [CrossRef]

118. Varshney, R.K.; Graner, A.; Sorrells, M.E. Genomics-assisted breeding for crop improvement. Trends Plant Sci. 2005, 10, 621-630. [CrossRef] [PubMed]

119. Gupta, P.K.; Varshney, R.K. Cereal Genomics: An Overview. In Cereal Genomics; Gupta, P.K., Varshney, R.K., Eds.; Springer: Dordrecht, The Netherlands, 2004.

120. Jacobs, D.I.; van der Heijden, R.; Verpoorte, R. Proteomics in plant biotechnology and secondary metabolism research. Phytochem. Anal. 2000, 11, 277-287. [CrossRef]

121. Hirano, H.; Islam, N.; Kawasaki, H. Technical aspects of functional proteomics in plants. Phytochemistry 2004, 65, 1487-1498. [CrossRef]

122. Bhushan, D.; Pandey, A.; Choudhary, M.K.; Datta, A.; Chakraborty, S.; Chakraborty, N. Comparative proteomics analysis of differentially expressed proteins in chickpea extracellular matrix during dehydration stress. Mol. Cell. Proteom. 2007, 6, 1868-1884. [CrossRef] 
123. Pandey, A.; Chakraborty, S.; Datta, A.; Chakraborty, N. Proteomics approach to identify dehydration responsive nuclear proteins from chickpea (Cicer arietinum L.). Mol. Cell. Proteom. 2008, 7, 88-107. [CrossRef]

124. Razzaq, A.; Sadia, B.; Raza, A.; Khalid, H.M.; Saleem, F. Metabolomics: A Way Forward for Crop Improvement. Metabolites 2019, 9, 303. [CrossRef]

125. Piasecka, A.; Kachlicki, P.; Stobiecki, M. Analytical Methods for Detection of Plant Metabolomes Changes in Response to Biotic and Abiotic Stresses. Int. J. Mol. Sci. 2019, 20, 379. [CrossRef]

126. Sung, J.; Lee, S.; Lee, Y.; Ha, S.; Song, B.; Kim, T.; Waters, B.M.; Krishnan, H.B. Metabolomic profiling from leaves and roots of tomato (Solanum lycopersicum L.) plants grown under nitrogen, phosphorus or potassium-deficient condition. Plant Sci. 2015, 241, 55-64. [CrossRef]

127. Dawid, C.; Hille, K. Functional Metabolomics-A useful tool to characterize stress-induced metabolome alterations opening new avenues towards tailoring food crop quality. Agronomy 2018, 8, 138. [CrossRef]

128. Fernie, A.R.; Schauer, N. Metabolomics-assisted breeding: A viable option for crop improvement? Trends Genet. 2009, 25, 39-48. [CrossRef] [PubMed]

129. Sauer, U.G.; Deferme, L.; Gribaldo, L.; Hackermüller, J.; Tralau, T.; van Ravenzwaay, B.; Yauk, C.; Poole, A.; Tong, W.; Gant, T.W. The challenge of the application of 'omics technologies in chemicals risk assessment: Background and outlook. Regul. Toxicol. Pharmacol. 2017, 91, S14-S26. [CrossRef] [PubMed]

130. Horgan, R.P.; Kenny, L.C. 'Omic' technologies: Genomics, transcriptomics, proteomics and metabolomics. Obstet. Gynaecol. 2011, 13, 189-195. [CrossRef]

131. Rakwal, R.; Hayashi, G.; Shibato, J.; Deepak, S.A.; Gundimeda, S.; Simha, U.; Padmanaban, A.; Gupta, R.; Han, S.-I.; Kim, S.T.; et al. Progress Toward Rice Seed OMICS in Low-Level Gamma Radiation Environment in Iitate Village, Fukushima. J. Hered. 2017, 109, 206-211. [CrossRef]

132. Heinig, U.; Gutensohn, M.; Dudareva, N.; Aharoni, A. The challenges of cellular compartmentalization in plant metabolic engineering. Curr. Opin. Biotechnol. 2013, 24, 239-246. [CrossRef]

133. Saito, K.; Matsuda, F. Metabolomics for functional genomics, systems biology, and biotechnology. Annu. Rev. Plant Biol. 2010, 61, 463-489. [CrossRef]

134. Tugizimana, F.; Mhlongo, M.I.; Piater, L.A.; Dubery, I.A. Metabolomics in Plant Priming Research: The Way Forward? Int. J. Mol. Sci. 2018, 19, 1759. [CrossRef]

135. Agarrwal, R.; Nair, S. Chapter 16-Metabolomics-assisted crop improvement. In Advancement in Crop Improvement Techniques; Tuteja, N., Tuteja, R., Passricha, N., Saifi, S.K., Eds.; Woodhead Publishing: Cambridge, UK, 2020; pp. 263-274.

136. Perumalsamy, S.; Bharani, M.; Sudha, M.; Nagarajan, P.; Arul, L.; Saraswathi, R.; Balasubramanian, P.; Ramalingam, J. Functional marker-assisted selection for bacterial leaf blight resistance genes in rice (Oryza sativa L.). Plant Breed. 2010, 129, 400-406. [CrossRef]

137. Arunakumari, K.; Durgarani, C.V.; Satturu, V.; Sarikonda, K.R.; Chittoor, P.D.R.; Vutukuri, B.; Laha, G.S.; Nelli, A.P.K.; Gattu, S.; Jamal, M.; et al. Marker-Assisted Pyramiding of Genes Conferring Resistance Against Bacterial Blight and Blast Diseases into Indian Rice Variety MTU1010. Rice Sci. 2016, 23, 306-316. [CrossRef]

138. Van Ooijen, J.W. JoinMap®4, Software for the Calculation of Genetic Linkage Maps in Experimental Populations; Kyazma BV: Wageningen, The Netherlands, 2006.

139. Richards, E.J. Inherited epigenetic variation-Revisiting soft inheritance. Nat. Rev. Genet. 2006, 7, $395-401$. [CrossRef] [PubMed]

140. Kumar, A.; Sandhu, N.; Dixit, S.; Yadav, S.; Swamy, B.P.M.; Shamsudin, N.A.A. Marker-assisted selection strategy to pyramid two or more QTLs for quantitative trait-grain yield under drought. Rice 2018, 11, 35. [CrossRef] [PubMed]

141. Angeles-Shim, R.B.; Reyes, V.P.; del Valle, M.M.; Lapis, R.S.; Shim, J.; Sunohara, H.; Jena, K.K.; Ashikari, M.; Doi, K. Marker-Assisted Introgression of Quantitative Resistance Gene pi21 Confers Broad Spectrum Resistance to Rice Blast. Rice Sci. 2020, 27, 113-123. [CrossRef]

142. Zorrilla-Fontanesi, Y.; Cabeza, A.; Domínguez, P.; Medina, J.J.; Valpuesta, V.; Denoyes-Rothan, B.; Sánchez-Sevilla, J.F.; Amaya, I. Quantitative trait loci and underlying candidate genes controlling agronomical and fruit quality traits in octoploid strawberry (Fragaria $\times$ ananassa). Theor. Appl. Genet. 2011, 123, 755-778. [CrossRef] 
143. Verma, S.; Zurn, J.D.; Salinas, N.; Mathey, M.M.; Denoyes, B.; Hancock, J.F.; Finn, C.E.; Bassil, N.V.; Whitaker, V.M. Clarifying sub-genomic positions of QTLs for flowering habit and fruit quality in U.S. strawberry (Fragaria $\times$ ananassa) breeding populations using pedigree-based QTL analysis. Hortic. Res. 2017, 4, 17062. [CrossRef]

144. Xin, F.; Zhu, T.; Wei, S.; Han, Y.; Zhao, Y.; Zhang, D.; Ma, L.; Ding, Q. QTL Mapping of Kernel Traits and Validation of a Major QTL for Kernel Length-Width Ratio Using SNP and Bulked Segregant Analysis in Wheat. Sci. Rep. 2020, 10, 25. [CrossRef]

145. Yousef, G.G.; Juvik, J.A. Comparison of Phenotypic and Marker-Assisted Selection for Quantitative Traits in Sweet Corn. Crop Sci. 2001, 41, 645-655. [CrossRef]

146. Robert, V.J.M.; West, M.A.L.; Inai, S.; Caines, A.; Arntzen, L.; Smith, J.K.; Clair, D.A. Marker-assisted introgression of blackmold resistance QTL alleles from wild Lycopersicon cheesmanii to cultivated tomato (L.esculentum) and evaluation of QTL phenotypic effects. Mol. Breed. 2001, 8, 217-233. [CrossRef]

147. Śliwka, J.; Jakuczun, H.; Chmielarz, M.; Hara, S.A.; Tomczyńska, I.; Kilian, A.; Zimnoch-Guzowska, E. Late blight resistance gene from Solanum ruiz-ceballosii is located on potato chromosome $\mathrm{X}$ and linked to violet flower colour. BMC Genet. 2012, 13, 11. [CrossRef]

148. Maruthasalam, S.; Kalpana, K.; Kumar, K.K.; Loganathan, M.; Poovannan, K.; Raja, J.A.J.; Kokiladevi, E.; Samiyappan, R.; Sudhakar, D.; Balasubramanian, P. Pyramiding transgenic resistance in elite indica rice cultivars against the sheath blight and bacterial blight. Plant Cell Rep. 2007, 26, 791-804. [CrossRef] [PubMed]

149. Jackson, R.E.; Bradley, J.R.J.; Van Duyn, J.W. Performance of Feral and Cry1Ac-Selected Helicoverpa zea (Lepidoptera: Noctuidae) Strains on Transgenic Cottons Expressing One or Two Bacillus thuringiensis ssp. kurstaki Proteins Under Greenhouse Conditions. J. Entomol. Sci. 2004, 39, 46-55. [CrossRef]

150. Puspito, A.N.; Rao, A.Q.; Hafeez, M.N.; Iqbal, M.S.; Bajwa, K.S.; Ali, Q.; Rashid, B.; Abbas, M.A.; Latif, A.; Shahid, A.A.; et al. Transformation and Evaluation of Cry1Ac+Cry2A and GTGene in Gossypium hirsutum L. Front. Plant Sci. 2015, 6, 943. [CrossRef]

151. Zhang, B.; Chi, D.; Hiebert, C.; Fetch, T.; McCallum, B.; Xue, A.; Cao, W.; Depauw, R.; Fedak, G. Pyramiding stem rust resistance genes to race TTKSK (Ug99) in wheat. Can. J. Plant Pathol. 2019, 41, 443-449. [CrossRef]

152. Ali, M.A.; Shahzadi, M.; Zahoor, A.; Dababat, A.A.; Toktay, H.; Bakhsh, A.; Nawaz, M.A.; Li, H. Resistance to Cereal Cyst Nematodes in Wheat and Barley: An Emphasis on Classical and Modern Approaches. Int. J. Mol. Sci. 2019, 20, 432. [CrossRef] [PubMed]

153. Liu, Y.; Santi, D.V. $\mathrm{m}^{5} \mathrm{C}$ RNA and $\mathrm{m}^{5} \mathrm{C}$ DNA methyl transferases use different cysteine residues as catalysts. Proc. Natl. Acad. Sci. USA 2000, 97, 8263-8265. [CrossRef]

154. Joseph, M.; Gopalakrishnan, S.; Sharma, R.K.; Singh, V.P.; Singh, A.K.; Singh, N.K.; Mohapatra, T. Combining bacterial blight resistance and Basmati quality characteristics by phenotypic and molecular marker-assisted selection in rice. Mol. Breed. 2004, 13, 377-387. [CrossRef]

155. Singh, S.; Sidhu, J.S.; Huang, N.; Vikal, Y.; Li, Z.; Brar, D.S.; Dhaliwal, H.S.; Khush, G.S. Pyramiding three bacterial blight resistance genes (xa5, xa13 and Xa21) using marker-assisted selection into indica rice cultivar PR106. Theor. Appl. Genet. 2001, 102, 1011-1015. [CrossRef]

156. Liu, Y.; Chen, L.; Liu, Y.; Dai, H.; He, J.; Kang, H.; Pan, G.; Huang, J.; Qiu, Z.; Wang, Q.; et al. Marker assisted pyramiding of two brown planthopper resistance genes, Bph3 and Bph27 (t), into elite rice Cultivars. Rice 2016, 9, 27. [CrossRef]

157. Narayanan, N.N.; Baisakh, N.; Vera Cruz, C.M.; Gnanamanickam, S.S.; Datta, K.; Datta, S.K. Molecular Breeding for the Development of Blast and Bacterial Blight Resistance in Rice cv. IR50. Crop Sci. 2002, 42, 2072-2079. [CrossRef]

158. Datta, K.; Baisakh, N.; Thet, K.M.; Tu, J.; Datta, S.K. Pyramiding transgenes for multiple resistance in rice against bacterial blight, yellow stem borer and sheath blight. Theor. Appl. Genet. 2002, 106, 1-8. [CrossRef] [PubMed]

159. Verlaan, M.G.; Hutton, S.F.; Ibrahem, R.M.; Kormelink, R.; Visser, R.G.F.; Scott, J.W.; Edwards, J.D.; Bai, Y. The Tomato Yellow Leaf Curl Virus resistance genes Ty- 1 and Ty-3 are allelic and code for DFDGD-class RNA-dependent RNA polymerases. PLoS Genet. 2013, 9, e1003399. [CrossRef]

160. Werner, K.; Friedt, W.; Ordon, F. Strategies for Pyramiding Resistance Genes Against the Barley Yellow Mosaic Virus Complex (BaMMV, BaYMV, BaYMV-2). Mol. Breed. 2005, 16, 45-55. [CrossRef] 
161. Castro, A.J.; Capettini, F.; Corey, A.E.; Filichkina, T.; Hayes, P.M.; Kleinhofs, A.; Kudrna, D.; Richardson, K.; Sandoval-Islas, S.; Rossi, C.; et al. Mapping and pyramiding of qualitative and quantitative resistance to stripe rust in barley. Theor. Appl. Genet. 2003, 107, 922-930. [CrossRef] [PubMed]

162. Jiang, F.; Zhang, T.; Bai, S.; Wang, Z.; He, K. Evaluation of Bt Corn with Pyramided Genes on Efficacy and Insect Resistance Management for the Asian Corn Borer in China. PLoS ONE 2016, 11, e0168442. [CrossRef] [PubMed]

163. Mehrotra, M.; Singh, A.K.; Sanyal, I.; Altosaar, I.; Amla, D.V. Pyramiding of modified cry1Ab and cry1Ac genes of Bacillus thuringiensis in transgenic chickpea (Cicer arietinum L.) for improved resistance to pod borer insect Helicoverpa armigera. Euphytica 2011, 182, 87. [CrossRef]

164. Djian, C.; Palloix, A.; Fazari, A.; Marteu, N.; Barbary, A.; Abad, P.; Sage-Palloix, A.-M.; Mateille, T.; Risso, S.; Lanza, R.; et al. Pyramiding, alternating or mixing: Comparative performances of deployment strategies of nematode resistance genes to promote plant resistance efficiency and durability. BMC Plant Biol. 2014, 14, 53. [CrossRef]

165. Yang, Z.; Huang, D.; Tang, W.; Zheng, Y.; Liang, K.; Cutler, A.J.; Wu, W. Mapping of quantitative trait loci underlying cold tolerance in rice seedlings via high-throughput sequencing of pooled extremes. PLoS ONE 2013, 8, e68433. [CrossRef]

166. Fujino, K.; Hirayama, Y.; Kaji, R. Marker-assisted selection in rice breeding programs in Hokkaido. Breed. Sci. 2019, 69, 383-392. [CrossRef]

167. Lin, R.; Zhao, W.; Meng, X.; Wang, M.; Peng, Y. Rice gene OsNAC19 encodes a novel NAC-domain transcription factor and responds to infection by Magnaporthe grisea. Plant Sci. 2007, 172, 120-130. [CrossRef]

168. Kim, Y.S.; Kim, I.S.; Shin, S.Y.; Park, T.H.; Park, H.M.; Kim, Y.H.; Lee, G.S.; Kang, H.G.; Lee, S.H.; Yoon, H.S. Overexpression of Dehydroascorbate Reductase Confers Enhanced Tolerance to Salt Stress in Rice Plants (Oryza sativa L. japonica). J. Agron. Crop Sci. 2014, 200, 444-456. [CrossRef]

169. Wang, A.; Yu, X.; Mao, Y.; Liu, Y.; Liu, G.; Liu, Y.; Niu, X. Overexpression of a small heat-shock-protein gene enhances tolerance to abiotic stresses in rice. Plant Breed. 2015, 134, 384-393. [CrossRef]

170. Kurokawa, Y.; Noda, T.; Yamagata, Y.; Angeles-Shim, R.; Sunohara, H.; Uehara, K.; Furuta, T.; Nagai, K.; Jena, K.K.; Yasui, H.; et al. Construction of a versatile SNP array for pyramiding useful genes of rice. Plant Sci. 2016, 242, 131-139. [CrossRef] [PubMed]

171. Jain, A.; Roorkiwal, M.; Kale, S.; Garg, V.; Yadala, R.; Varshney, R.K. InDel markers: An extended marker resource for molecular breeding in chickpea. PLoS ONE 2019, 14, e0213999. [CrossRef] [PubMed]

172. Gelli, M.; Konda, A.R.; Liu, K.; Zhang, C.; Clemente, T.E.; Holding, D.R.; Dweikat, I.M. Validation of QTL mapping and transcriptome profiling for identification of candidate genes associated with nitrogen stress tolerance in sorghum. BMC Plant Biol. 2017, 17, 123. [CrossRef]

173. Forster, B.P.; Ellis, R.P.; Thomas, W.T.B.; Newton, A.C.; Tuberosa, R.; This, D.; El-Enein, R.A.; Bahri, M.H.; Ben Salem, M. The development and application of molecular markers for abiotic stress tolerance in barley. J. Exp. Bot. 2000, 51, 19-27. [CrossRef]

174. Collard, B.C.Y.; Jahufer, M.Z.Z.; Brouwer, J.B.; Pang, E.C.K. An introduction to markers, quantitative trait loci (QTL) mapping and marker-assisted selection for crop improvement: The basic concepts. Euphytica 2005, 142, 169-196. [CrossRef]

175. Nevame, A.Y.M.; Xia, L.; Nchongboh, C.G.; Hasan, M.M.; Alam, M.A.; Yongbo, L.; Wenting, Z.; Yafei, H.; Emon, R.M.; Ismail, M.R.; et al. Development of a New Molecular Marker for the Resistance to Tomato Yellow Leaf Curl Virus. Biomed Res. Int. 2018, 2018, 8120281. [CrossRef]

176. Beukeboom, L.W.; Niehuis, O.; Pannebakker, B.A.; Koevoets, T.; Gibson, J.D.; Shuker, D.M.; van de Zande, L.; Gadau, J. A comparison of recombination frequencies in intraspecific versus interspecific mapping populations of Nasonia. Heredity 2010, 104, 302-309. [CrossRef]

177. Mageto, E.K.; Lee, M.; Dhliwayo, T.; Palacios-Rojas, N.; San Vicente, F.; Burgueño, J.; Hallauer, A.R. An Evaluation of Kernel Zinc in Hybrids of Elite Quality Protein Maize (QPM) and Non-QPM Inbred Lines Adapted to the Tropics Based on a Mating Design. Agronomy 2020, 10, 695. [CrossRef]

178. Wang, X.; Xu, Y.; Hu, Z.; Xu, C. Genomic selection methods for crop improvement: Current status and prospects. Crop J. 2018, 6, 330-340. [CrossRef]

179. Bhatia, D. Advanced Quantitative Genetics Technologies for Accelerating Plant Breeding. In Accelerated Plant Breeding; Gosal, S., Wani, S., Eds.; Springer: Cham, Switzerland, 2020; Volume 1. 
180. Weiwei, W.; Haijun, L.; Zhou, Y.; Min, J.; Ning, Y.; Dong, L.; Jie, L.; Yingjie, X.; Qingchun, P.; Takayuki, T.; et al. Combining Quantitative Genetics Approaches with Regulatory Network Analysis to Dissect the Complex Metabolism of the Maize Kernel. Plant Physiol. 2016, 170, 136-146.

181. Watson, A.; Ghosh, S.; Williams, M.J.; Cuddy, W.; Simmonds, J.; Rey, M.-D.; Asyraf Hatta, M.; Hinchliffe, A.; Steed, A.; Reynolds, D.; et al. Speed breeding is a powerful tool to accelerate crop research and breeding. Nat. Plants 2018, 4, 23-29. [CrossRef]

182. Gosal, S.S.; Pathak, D.; Wani, S.H.; Vij, S.; Pathak, M. Accelerated Breeding of Plants: Methods and Applications. In Accelerated Plant Breeding; Gosal, S., Wani, S., Eds.; Springer: Cham, Switzerland, 2020; Volume 1.

183. Gao, H.; Christensen, O.F.; Madsen, P.; Nielsen, U.S.; Zhang, Y.; Lund, M.S.; Su, G. Comparison on genomic predictions using three GBLUP methods and two single-step blending methods in the Nordic Holstein population. Genet. Sel. Evol. 2012, 44, 8. [CrossRef] [PubMed]

184. Libbrecht, M.W.; Noble, W.S. Machine learning applications in genetics and genomics. Nat. Rev. Genet. 2015, 16, 321-332. [CrossRef] [PubMed]

185. Wen, X. Bayesian model selection in complex linear systems, as illustrated in genetic association studies. Biometrics 2014, 70, 73-83. [CrossRef]

186. Devi, E.L.; Devi, C.P.; Kumar, S.; Sharma, S.K.; Beemrote, A.; Chongtham, S.K.; Singh, C.H.; Tania, C.; Singh, T.B.; Ningombam, A.; et al. Marker assisted selection (MAS) towards generating stress tolerant crop plants. Plant Gene 2017, 11, 205-218. [CrossRef]

(C) 2020 by the authors. Licensee MDPI, Basel, Switzerland. This article is an open access article distributed under the terms and conditions of the Creative Commons Attribution (CC BY) license (http://creativecommons.org/licenses/by/4.0/). 